371.3::811.111'243

https://doi.org/10.18485/sj.2019.24.1.22

IVANA R. ĆIRKOVIĆ-MILADINOVIĆ

University of Kragujevac

Faculty of Education in Jagodina

MARIJANA D. MATIĆ*

University of Kragujevac

Faculty of Philology and Arts
Оригинални научни рад

Примљен: 11. 09. 2018.

Прихваћен: 15. 01. 2019.

\title{
THE FREQUENCY AND USAGE OF FOREIGN LANGUAGE LEARNING STRATEGIES: A COMPARATIVE STUDY
}

The aim of the paper is to explain the frequency and usage of the foreign language learning strategies (LLS) as one of the very important preconditions for the successful individual learning at the university level. Both efficacy and the teaching quality of the English language represent significant factors of the university learning improvement. Furthermore, the students' competency depends on the quality and the achievement of the English language educational tasks both in the language area and in reading the English literature for specific purposes. Reading the foreign language literature would contribute to students' effective dealing with the future professional tasks. The main purpose of the research was to determine the frequency of using the language learning strategies in learning English as a foreign language at the Faculty of Education in Jagodina and Faculty of Philology and Arts in Kragujevac. The focus of this research was to compare two groups of students in terms of LLS usage and to explain the differences that emerged. The potential of the research results lies in the prepositions of teaching the language learning strategies at the university level with

*merimaks@gmail.com 
the aim to help students to use English in a more effective way in order to improve themselves in their future professions.

Key words: language learning strategies, SILL, the English language, students at university level.

\section{INTRODUCTION}

With regard to the research into learning strategies, interest in identifying what learners do to learn a second/foreign language seems to have begun in the mid-1970s, when it was very important for the researchers to discover strategies used by good language learners. It was believed that such research on learning strategies could have two major advantages. The first one it would be to improve teaching quality while the other was to encourage less successful learners to improve their performance by paying more attention to good language learners' strategies. However, the question being asked in the literature of SLA/FLA is, once successful learning strategies have been identified, would it be feasible to teach them to poor language learners.

There have been a few definitions of language learning strategies and learning strategies since 1970s. They have all attempted at shedding light on what learners think and do during language learning. In this context, Faerch, Claus and Casper (1983: 23) define the concept of a learning strategy as an attempt to develop linguistic and sociolinguistic competence in the target language, whereas Wenden and Rubin (1987: 17) describe them as any set of operations, steps, plans, routines used by a learner to facilitate the obtaining, storage, retrieval and use of information. Cohen (1990: 29) states that learning strategies are consciously selected process by learners which may result in actions taken to enhance the learning or use of a second or foreign language through storage, retention and application of the information about the language. Oxford (in 1990) concludes that the context is essential in the language learning process and considers language learning strategies as intentions to do and specific actions to undertake planned by a learner. They are specific actions taken by the learner to make learning easier, faster, more enjoyable, more self-directed, more effective, and more transferable to new situations. All the scientists looking into language learning strategies agree that the usage of the language learning strategies is absolutely necessary whether used subconsciously or consciously.

According to McDonough (2006) good language learners have a certain degree of flexibility when learning, while people who are less successful in that respect, have less flexibility. Further, he comes to a conclusion that the distinction between the good and poor language learners is not so much that they are using a whole different class of strategies. In many cases, they are using the same strate- 
gies, but the good language learners of course are using them successfully and the poor language learners are having difficulty about and failing to use them properly. He is supported by Pani (2004) who states that good readers apply more strategies more frequently and more effectively than poor readers. Accordingly, a number of researches argue that it would be possible to help ineffective learners to develop their skills by integrating strategy training programmes in English classes (Wenden and Rubin, 1987; Oxford, 1990; O'Maley and Chamot, 1990). In this regard, Rubin (1975) seems to be convinced of the 'teachability' of learning strategies by saying that if we knew more about successful learners and the language learning strategies (LLS) they use, we might be able to teach these strategies to poor language learners. In his study Rubin (ibid.) tried to identify effective LLS. Òhus, good learners have some characteristics as follows: 1) The good language learner is a willing and accurate guesser who has a strong drive to communicate or to learn from communication; 2) The good language learner is often not inhibited and is prepared to attend to form and meaning; 3 ) He practices pronouncing words or making up sentences and monitors his own and the speech of others (Rubin, 1975: 45-47). So, Rubin (ibid.) proposes that once good language learners' strategies have been identified, they could be utilized by less successful learners.

On the whole, it can be noticed that most of the studies dealing with good versus poor language learning strategies focused mainly on comparing two main characteristics: quantity and frequency of language learning strategy usage. Nevertheless, Oxford (2001) points out that these two aspects are not always the only distinguishing ones. She adds that there is sufficient evidence that some learners become more successful than others because they are aware of the fact that different language tasks demand different language strategies. Hence, good language learners know which strategies to apply to particular language tasks. Furthermore, good language learners know better to combine strategies when they are necessary and where necessary (Abraham and Vann, cited in Oxford, 2001).

\section{STRATEGY TRAINING}

Second or foreign language learners do not enter the language classroom as tabula rasa, rather they are speaking human beings who know great deal about language and communication. Therefore, there is a growing interest in changing the focus of classrooms from a teacher-centered one to a learner-centered one and in clarifying how teachers can help students become more autonomous.

In the field of teacher education autonomy is widely regarded as a 'capacity for potential self-directed learning behaviours' (Sinclair 1999:311) McGrath (2000) points out two perspectives of teacher autonomy: 1) teacher autonomy as self-directed professional development where the teacher is a learner himself and 
2) teacher autonomy as freedom from control by others where subject teachers are expected to act within a triangular structure of syllabus, examination system and textbook. He then goes on to explain another aspect of teacher education which is preparing teachers to facilitate learner autonomy. Teachers facilitate learner autonomy while being learners at the same time. This aspect of teacher education is something that seems important for strategy instruction issue because being a learner himself the teacher might better foster and better understand learners' needs in the language classroom.

Further, Brandt (2006: 362) suggests that teacher training concept needs to move away from a 'being told' transfer approach, which is expert-directed, towards an 'exploratory approach', which allows for different teaching and learning styles and encourages autonomy as well as critical reflection for the teacher. Wright (1987) echoes Brandt's view by proposing that language teachers in a process of continual professional development should take the initiative themselves in pedagogic planning and put the emphasis on critical enquiry as a basis for effective action in their teaching practice (TP). Namely, teacher who is willing to explore his/her teaching practice in order to discover learners' needs and preferences may contribute to learner autonomy achievement. Thus, this point accounts for the fact that language teachers capable of exploring TP and helping their learners in the process of learning to focus on how to learn rather on what to learn are more likely to make learners' autonomy plausible (Dickinson 1992). In this way, learners may become more motivated and independent in the process of learning and using learning strategies while the teacher may become more motivated and willing for the both exploration of the teaching practice and language learning strategies.

Waters (1988) advocates that the subject matter in teacher training courses should not only be theoretically sound but should also be the kind of thing the trainees will readily identify with and apply those ideas in their classrooms. Teacher training may directly contribute to the learner training by enhancing learners' language learning outcomes. For this reason, Chen (2007) points out that strategy training helps students' become aware of using comprehension strategies in their learning. Hence, the purpose of learner training is to make everyone a better learner as well as to enhance the effectiveness of the language learning process (Dickinson 1992).

One of the possibilities to examine the usefulness of the teacher training may be through feasibility of applying strategy training theory into teaching practice. A more subtle outcome may be also applied: strategy training may raise student awareness of the purpose and rationale of strategy use; it would give students opportunities to practice the strategies they are being taught, and help them use the strategies in new learning contexts. 


\section{FUTURE TEACHERS AS FOREIGN LANGUAGE LEARNERS}

As can be perceived in recent papers in the field of teacher education is that learning constitutes an important part of being a teacher (e.g. Smith 2000; McDonough 2002). Therefore, long-term professional development is essential for every teacher and can be realised either through individual development or through in-service training.

It may be said that teachers are individuals and their styles are different as well as their teaching skills. Teachers possess a mixture of skills, attitudes, values, beliefs and knowledge areas, yet this mixture should not be observed as a disadvantage but, on the contrary, this variety seem to be a great benefit for the ELT practice (Woodward 1991). In general, "teachers and future teachers benefit from the opportunity to reflect on the experience of being language learners, which should be varied and ongoing" (Hyde, 2000: 271).

To sum up briefly, being open to variety of principles and able to think about, discuss and change them in the light of work experience is according to Woodward (ibid.) definition of a good teacher as a learner and a good teacher as a professional. A teacher like that would be in position to conduct a research for his own purposes in order to realize better the situation in the classroom and in that way help his learners to overcome learning problems by using language learning strategies.

\section{SELF-DIRECTED LEARNING}

Just like teachers, different students have different learning styles and use different learning strategies. The more teachers know about their students' learning style and strategy preference the more effectively they can orient their strategy instruction. Oxford (2001a) points out those L2 teachers should consider various ways to conduct strategy instruction in their language classrooms by starting with small strategy interventions, such as helping students to analyse and guess the word they are not familiar with from a given text. This would be more appropriate, than to apply full range of strategy-based instruction (ibid.). Strategy training is defined as the explicit teaching of how, when, and why students should use FL learning strategies to improve their efforts at achieving language learning outcomes (Cohen 1998; Ellis and Sinclair 1989).

On the other hand, some teachers might find it useful and appropriate to move more rapidly into strategies-based instruction. Cognitive Academic Language Learning Approach (CALLA) model for example, as described by Chamot and O'Malley (1996) is a form of strategy-based instruction for L2 learners which includes explicit 
strategy instruction, content area instruction and academic language development. For example Anderson's theory support teaching approaches which "combine the development of content knowledge, practice in using this language and strategy training to promote independent learning" (Anderson, 1993 cited in Snow 2001:304). In the university teaching context it is very important that students, as adult learners, do initiate their own learning (Wenden and Rubin 1987). In this way, students as autonomous language learners can become more intimately involved in providing solutions to their linguistic needs as they arise (Cirkovic-Miladinovic, 2014). It is further stated that for learning to be autonomous, learners need a critical awareness and understanding of the ability to make choices and, thereof, become responsible for their learning outcomes.

Since the 1970s, researchers have addressed the need for strategy training in response to the lack of students' awareness of the cognitive tools and strategies available to them (Chen, 2007). Dansereau (1978) reports for instance, that a large proportion of the participants have little knowledge of alternative learning techniques, including proficient university-level students. This lack of awareness is limiting the learners' ability to develop new strategies when encountering new learning contexts. Therefore, together with the training in the use of strategies, the fostering of learner autonomy and expanding learners' views of what language means will require that learners become critically reflective of their learning. Accordingly, the purpose of learning a second/foreign language should also be understood.

In Vogely's findings (cited in Chen 2007), students' learning problems are due to the use of inadequate or inappropriate learning strategies. According to those findings students who even know about the learning strategies necessary to comprehend language tasks, do not mobilize these resources to the fullest extent. Oxford (2001) also cites growing evidence that strategy instruction can be valuable to many language learners. Thus, this should be the starting point for the teachers' practice: strategy instruction may enhance students' language learning outcomes. For this reason, research in strategy training seems valuable for the improvement of the English teaching practice in Serbia.

\section{RESEARCH METHOD}

For the purpose of this research we used Strategy Inventory for Language Learning or SILL (Oxford 1990) which was designed to elicit students' habits and frequency of use of direct (memory, cognitive, compensation strategies) and indirect language learning strategies (metacognitive, affective, and social strategies, respectively). As stated by Oxford all the direct strategies involve mental processing of the language whereas indirect strategies provide indirect support for language learning. 
The study aimed to explain the frequency and usage of the foreign language learning strategies (LLS) as one of the very important preconditions for the successful individual learning at the university level. The main purpose of the research was to determine the frequency of using the language learning strategies in learning English as a foreign language at the Faculty of Education in Jagodina and Faculty of Philology and Arts in Kragujevac. The focus of this research was to compare two groups of students in terms of LLS usage and to explain the differences that emerged.

\subsection{Research instrument}

The chosen instrument for this research was a questionnaire. The reason for this was that questionnaires are economical in terms of time (they are usually easy to complete) and money; then researcher can reach large number of respondents who receive the same questions usually quick to complete. Also, questionnaires tend to be quantitative and more easily generate conclusive findings (Wallace, 1998). "SILL is a self-scoring paper-and-pencil survey which consists of statements such as 'I start conversations in English', or 'I ask questions in English', to which students are asked to respond on a 5-point Likert scale ranging from 1 (never, or almost never) to 5 (always, or almost always)" (Griffiths and Parr, 2001: 250-251). The 50 items of the ESL/EFL version of the SILL are divided into the following six groups:

Memory strategies: relating to how students remember language, such as 'I use flashcards to remember new English words', or 'I review English lessons often' (items one to nine).

Cognitive strategies: relating to how students think about their learning, such as 'I read for pleasure in English', or 'I try to find patterns in English' (items ten to twenty three).

Compensation strategies: these enable students to make up for limited knowledge, such as 'I read English without looking up every new word', or 'To understand unfamiliar English words I make guesses (items twenty four to twenty nine)'.

Metacognitive strategies: relating to how students manage their own learning, such as 'I notice my English mistakes and use that information to help me do better', or 'I plan my schedule so that I will have enough time to study English' items thirty to thirty nine).

Social strategies: refer to cooperation with others, such as 'I practice English with other students', or 'I ask for help from English speakers' (items forty to forty four).

Affective strategies: relating to students' feelings, such as 'I try to relax whenever I feel afraid of using English', or 'I try to learn about the culture of English speakers' (items forty five to fifty). 


\subsection{Respondent details}

A sample of 176 students completed the SILL (Oxford 1990: 293-6). There were male and female students of the first academic year. These students study English as a foreign language. Students at the Faculty of Education in Jagodina (sample of 114 students) study General English as obligatory academic subject during the first academic year. Namely, in the first academic year they study the English language grammar, vocabulary, pronunciation, speaking, writing, reading, listening etc., while in their second academic year they study English with the stress on the occupational purposes for their future profession - primary school teacher. For the purposes of this paper we conducted a research only with freshmen on both faculties. A sample of 62 (out of 176) freshmen students completed SILL at the Faculty of Philology and Arts in Kragujevac. These students study to be future English teachers and English Language Course (which also includes learning about grammar, speaking, writing, reading, listening and vocabulary) is just one of the courses that are offered to these students in this teaching area. They also study different subjects about the language structure (on the first year, for example, English phonetics and phonology) and about English literature (the medieval and the renaissance period on the first year). For these students the subject of English language teaching and learning both from the theoretical and practical point of view is introduced in the final year of study ( $4^{\text {th }}$ year), and subjects like general psychology and pedagogy are introduced in the second year of study.

What can be deduced from these data is the fact that all respondents are future teachers who have very challenging, and above all, very pleasant profession - to teach pupils how to learn certain content and to prepare them to readily face future learning problems. What is more, to prepare them to be independent learners.

The research respondents were from different hometowns with different social status. Their social status and their background are irrelevant for this study so for the reason of space we will not discuss these matters here in this paper. What is important for us in this study is to find out what learning strategies students mostly use in this teaching context (university teaching context in Serbia) and to compare two mentioned group of students in terms of LLS usage and to explain the differences/similarities that emerged.

\section{RESULTS}

The average for each group of strategies has been calculated for each student, they were added and divided by the number of students and thus the mean for each group of strategies for each group of students was calculated. According to Oxford (1990: 28) the key to understanding the average is as follows: 


$\begin{array}{lll}\text { HIGH } & \text { Always or almost always used } & 4.5 \text { to } 5.0 \\ & \text { Usually used } & 3.5 \text { to } 4.4 \\ \text { MEDIUM } & \text { Sometimes used } & 2.5 \text { to } 3.4\end{array}$

$\begin{array}{lll}\text { LOW } & \text { Generally not used } & 1.5 \text { to } 2.4 \\ & \text { Never or almost never used } & 1.0 \text { to } 1.4\end{array}$

As can be seen when comparing the tables (Table 1 and Table 2) both groups of students used the metacognitive strategies when learning English as a foreign language most frequently, as they ranked the highest 3.79 for English language and literature students and 3.70 for the primary school teachers. This means that both groups of students claim to give great importance to managing their own learning of English in respect to their goals in learning English, finding ways to be better learners and looking for opportunities for learning English or paying attention when someone speaks English.

Table 1. LLS rank according to categories - respondents students at the Faculty of Education in Jagodina, department: class teachers

\begin{tabular}{|l|l|}
\hline \multicolumn{2}{|c|}{$\begin{array}{c}\text { LLS rank according to categories } \\
\text { Class teachers }\end{array}$} \\
\hline Part D - metacognitive strategies most frequent & 3.70 \\
\hline Part F - social strategies & 3.59 \\
\hline Part B - cognitive strategies & 3.33 \\
\hline Part C - compensation strategies & 3.10 \\
\hline Part A - memory strategies & 2.75 \\
\hline Part E - affective strategies least frequent & 2.33 \\
\hline
\end{tabular}

As the least frequent learning strategy both groups of students ranked the affective strategies. The score is 2.31 for the future English language teachers and 2.33 for the class teachers. This means that both groups of students claim they generally 
do not use strategies to put their affective filter down or to overcome their anxiety and give themselves encouragement when learning English. They generally do not discuss their feelings with their mates or note down their feelings in any way. Learning about English culture is not among their learning goals or strategies.

Table 2. LLS rank according to categories - respondents - students at the Faculty of Philology and Art in Kragujevac, department: English language and literature

\begin{tabular}{|l|l|}
\hline \multicolumn{2}{|c|}{$\begin{array}{c}\text { LLS rank according to categories } \\
\text { Students of English }\end{array}$} \\
\hline Part D - metacognitive strategies most frequent & 3.79 \\
\hline Part B - cognitive strategies & 3.69 \\
\hline Part C - compensation strategies & 3.43 \\
\hline Part A - memory strategies & 3.06 \\
\hline Part F - social strategies & 2.75 \\
\hline Part E - affective strategies least frequent & 2.31 \\
\hline
\end{tabular}

In case of class teachers, the second most frequent group of strategies used are social strategies, with the score 3.59 , which means that they cooperate with others when learning English, practice with other students, and if given an opportunity ask for help from English speakers.

Unlike them the second most frequent strategy for future English language teachers are the cognitive strategies ranked 3.69. This means that students generally think about their learning in terms of finding patterns in English, reading for pleasure in English, reading a text firstly by skimming it and then reading it in-depth, trying to understand the word by dividing it into parts (root, prefixes, suffixes etc.), using the words they know in different ways and similar.

The same strategy is ranked the third most frequent for the class teachers. Namely, they sometimes use the cognitive strategies when learning English and the score is 3.33. The reason for this is that they are not yet familiar with the academic subjects that deal with the process of learning a certain content (such subjects are: didactics, educational psychology, methodology of teaching etc.).

The third most frequent group of strategies sometimes used by the future English language teachers are compensation strategies, ranked 3.43. This group of strategies is ranked fourth and also sometimes used by the class teachers, is ranked 3.10. Compensation strategies are the ones the students turn to when their 
knowledge of or about the language is insufficient. Strategies such as "to understand unfamiliar English words, I make guesses", "I make up new words if I do not know the right ones in English", "If I can't think of an English word, I use a word or phrase that means the same in English", and "I try to guess what the other person will say next in English".

The memory strategies ranked fourth in the case of future English teacher with the score 3.06 (thus sometimes used) and fifth in the case of class teachers with the score 2.75 (thus sometimes used). This means that students sometimes use the strategies of thinking about the relationships between what they already know and what they learn in English. They also use new English words in a sentence in order to remember them better. Using flashcards to remember new words in English and connecting the sounds of a new word and an image and picture in order to remember them also belong to memory strategies.

Social strategies are ranked the fifth in the case of the future English language teachers and score 2.75 , which means that they are sometimes used by them.

\section{DISCUSSION}

As can be observed from the above presented data both groups of students use language learning strategies but the frequency is different. It goes from usually used, through sometimes used, to generally not used, thus ranking from 3.79 to 2.31. There are no strategies which prove to be always or almost always used. This leads us to the conclusion that both groups of students do not use to the full extent any language learning strategies.

What both groups share is the most and least frequent groups of strategies used, metacognitive and affective strategies respectively. When metacognitive strategies are concerned, it is important to note that both groups of students manage rather well their own foreign language learning both in the sense that they notice their mistakes and use that information to get better on one hand, and on the other hand, plan their schedule to have enough time and opportunity to learn English. We consider it important for the future teachers to be aware of their own learning and be able to act according to that specific experience, which is in line with the previously presented opinions of all researchers and methodologists. As for the use of the affective strategies, we can conclude that the result in frequency in both groups can be prescribed to the cultural setting of the Serbian society and learning environment where it is not common to discuss, at least not publicly or systematically (as in language learning diaries) their feelings towards their process of learning or to have information what to do in cases of fears, inhibitions or anxiety when learning or producing a foreign language. 
It is also interesting to note the difference between the two groups in ranking other strategies that follow metacognitive ones. In case of future primary school teachers, the second frequent group of strategies are social strategies, whereas in the case of future English language teachers, the second in rank are the metacognitive strategies. The difference can probably be ascribed to the fact that future primary school teachers are from the beginning of their study at the Faculty of Education engaged in group work, discussions and reliance on others, whereas in the case of future English teachers, most of the time spent learning English at the Faculty level is only partly devoted to the subject of English language course and within this subjects different classes are only sporadically working in smaller groups or pairs. Another possible reason is that future primary school teachers seem to have a somewhat clearer idea of their future social role when finishing the university from the very beginning of their study, as compared to future English language teachers who can decide between being a teacher or an interpreter later during their university study. Thus, aware of their future social role as primary school teachers, when using language learning strategies as learner, primary school teachers apply the social strategies more.

It is also important to note that in case of both groups, according to their mutual ranking and frequency, the following strategies are used in the same order: cognitive, compensation and then memory strategies. It seems that irrespective of their field of study both groups of students when learning English as a foreign language at the university level give more importance to their way of thinking about their own learning and try to improve that, and then to compensate for their limited knowledge by different compensation strategies, followed by different memory strategies which enable them to memorise the patterns, words and meanings.

\section{PEDAGOGICAL IMPLICATIONS}

The results discussed above imply that both groups of students do not use any of the language learning strategies to the full extent, as there are no strategies which are always or almost always used, which means that possible future instruction about language learning strategies would be highly beneficial for both groups of students as learners and more importantly as teachers of future independent learners. Apart from that, systematic instruction and practice of different groups of strategies and different strategies within one group of strategies would foster both groups of students' learning and provide them with invaluable opportunity to provide solutions to their own linguistic needs, be more aware of their learning preferences, and thus become more understandable and open-minded towards the language learning process of their own learners in the future and ways how to facilitate their learning autonomy. According to Westwood and Arnold (2004) it is 
highly desirable for teachers to recognize individual differences among learners and to use methods that allow them to address these differences in positive ways. This is where strategy training and strategy research is taking place. Both groups of students should also be acquainted with language learning process at the academic level from the theoretical point of view, including information about different types of learners, key elements to being an autonomous learner, to the practical point of view, giving clear instruction which aim is to help in producing autonomous learners able to learn individually and to monitor their learning as well. However, research on students' individual needs, in several countries, has indicated that teachers do not find differentiation easy to implement (e.g. Westwood, 2002). It is also important to include other information which will enable future primary teachers and English teachers to become independent within the triangular structure: syllabus, examination system and textbook. Exploring language learning strategies and learning about them will certainly play an important part in that process.

\section{CONCLUSION}

When including strategies-based instruction in a foreign language curriculum, it is important to choose an instructional model that introduces the strategies to the students and raises awareness of their learning preferences, teaches them to identify, practice, evaluate, and transfer strategies to new learning situations, and promotes learner autonomy to enable students to continue their learning after they leave the language classroom (Cohen, 2003).

Yet, scepticism is also well-placed when it comes to applying the strategy training in university teaching context because it is widely believed that students are adult learners who know how to learn (this is to a certain extent students' opinion and to some extent teachers' opinion). Nevertheless, students' achievements in exams show that they do encounter learning problems and that they do need teacher's professional help (Cirkovic-Miladinovic, 2014a). Thus, teachers' practices and perceptions are significant in terms of strategy training since they have the potential to influence the effectiveness of their students' learning process (ibid.).

Interestingly, it is not so much all the strategies that teachers could teach and their students to use; it is how they use them, when they use them, how they decide what is working or not working for them at a particular situation, when they decide to use something else, how they deal with the product of that strategy and how it helps them to take over some of the decision making for their own language learning outcome. In other words, there are lots of questions that could be answered by, for instance, conducting the strategy research. Strategy research seems to be crucial for the learner training in the university teaching context in Serbia because it would give teachers clear and practical notion of what learners actually do and 
what are the benefits, or even drawbacks, of this instruction (Archibald and McDonough 2006).

Exploring strategies would help teachers realize that, for instance, more speaking does not necessarily mean better speaking or more reading does not automatically mean better reading (Field 1998). Still, practicing strategies in the language classroom would result in using them with less effort and, at the same time, more successful dealing with language tasks would become part of the learning atmosphere (Ridgeway 2000). Hence, according to this, both strategy training and strategy research seem very important for all language skills. Although strategy research is very important in the language learning field, it is not practiced very much in the university level.

In conclusion, we would like to point out that we need lots more of that kind of research and it could be incorporated into teacher training in very productive ways. It is being done, but it seems that it is an area that could be expanded quite a lot in our universities.

\section{REFERENCES}

Archibald/McDonough 2006: Archibald, A. and McDonough, S., "Learner strategies: An interview with Steven McDonough" ELT Journal, Vol. 60/1: 63-70. Oxford: Oxford University Press.

Brandt 2006: Brandt, C., Allowing for practice: a critical issue in TESOL teacher preparation. ELT Journal, Vol. 60/4: 355-364. Oxford: Oxford University Press.

Cirkovic Miladinovic 2014: Cirkovic-Miladinovic, I., Strategy Research in ELT: The Benefits for the Teacher. ISBN: 978-3-659-57760-4. Publisher: Saarbrucken, Deutschland: LAP Lambert Academic Publishing.

Cirkovic Miladinovic 2014a: Cirkovic-Miladinovic, I., Zastupljenost afektivnih strategija učenja engleskog jezika kod studenata na nematičnim fakultetima. Neobjavljena doktorska disertacija, odbranjena 4. 6. 2014. na Filozofskom fakultetu u Novom Sadu.

Chen 2007: Chen, Y., Learning to learn: the impact of strategy training, in ELT Journal, Vol. 61/1: 20-29. Oxford: Oxford University Press.

Chamot/O'Malley 1994: Chamot, A. U., \& O'Malley, J. M., The CALLA handbook: Implementing the cognitive academic language learning approach. Reading, MA: Addison-Wesley Publishing Company. 
Chamot/O'Malley 1996: Chamot, A. U. and O'Malley, J. M., The Elementary School Journal, Vol. 96, No. 3, Special Issue: The Language-Minority Student in Transition, pp. 259-273.

Cohen 1990: Cohen, A., Language learning: Insights for learner, teachers and researchers. New York. Newbury House.

Cohen 1998: Cohen, A. D., Strategies in Learning and Using a Second Language. London: Longman.

Cohen 2003: Cohen, A. D., Strategy Training for Second Language Learners, Center for Advanced Research on Language Acquisition, University of Minnesota, ERIC clearinghouse on languages and linguistics $\bullet 4646$ 40th ST NW • Washington dc 20016-1859 • 202-362-0700, Taken form: eric@cal.org on August 2015.

Dansereau 1978: Dansereau, D. F., 'The development of a learning strategies curriculum' in H. F. O’Neil, Jr. (ed.). Learning Strategies. New York: Academic Press.

Dickinson 1992: Dickinson, L., Learner Autonomy 2: Learner Training for Language Learning. Dublin: Authentik.

Ellis/Sinclair 1989: Ellis, G. and B. Sinclair, Learning to Learn English: A Course in Learner Training. Cambridge: Cambridge University Press.

Faerch/Kasper 1983: Faerch, C. and G. Kasper, Strategies in Interlanguage Communication. London: Longman.

Field 1998: Field, J., 'Skills and strategies: towards a new methodology for listening'. ELT Journal, 52/2: 110-8. Oxford: Oxford University Press.

Griffiths/Paar 2001: Griffiths, C. and Parr, J. M., "Language-learning strategies: theory and perception" ELT Journal, Vol. 55/3: 247-254. Oxford: Oxford University Press.

Hyde 2000: Hyde, B., Teachers as learners: beyond language learning. ELT Journal Vol.54/3: 265-273. Oxford: Oxford University Press.

McDonough 2002: McDonough, J., The teacher as language learner: worlds of difference, in ELT Journal, Vol. 56/4: 404-411. Oxford: Oxford University Press.

McDonough 2006: McDonough, K., Responses to recasts: Repetitions, primed production, and linguistic development. Language Learning, 693-720. Blackwell Publishing Inc.

McGrath 1997: McGrath, I. (ed.), Learning to Train: Perspectives on the Development of Language Teacher Trainers. Prentice Hall Europe in association with The British Council 
McGrath 2000: McGrath, I., 'Teacher Autonomy' in Sinclair, B., McGrath, I. and Lamb, T. ed., Learner Autonomy, Teacher Autonomy: Future Directions, pp. 100-110. Longman, London.

O'Malley/Chamot 1990: O'Malley, J. M. and A. U. Chamot, Learning Strategies in Second Language Acquisition. Cambridge: Cambridge University Press.

Oxford 1990: Oxford, R., Language Learning Strategies: What Every Teacher Should Know. New York: Newbury House.

Oxford 2001: Oxford, R. L., "Language Learning Strategies" in Carter, R. and Nunan, D. (eds.) The Cambridge Guide to Teaching English to Speakers of Other Languages. Cambridge: Cambridge University Press.

Oxford 2001a: Oxford, R. L., "Language Learning Styles and Strategies" in CelceMurcia M. (ed.), Teaching English as a Second or Foreign Language, pp. 359-366. Heinle \& Heinle, USA.

Pani 2004: Pani, S., Reading strategy instruction through mental modeling” ELT Journal, Vol. 58/4: 355-362. Oxford: Oxford University Press.

Ridgeway 2000: Ridgeway, T., "Listening strategies - I beg your pardon? ELT Journal, Vol. 54/2: 179-185. Oxford: Oxford University Press.

Rubin 1975: Rubin, J., “What the „Good Language Learner” can teach us'. TESOL Quarterly 9/1: 41-51. TESOL International Association.

Sinclair 1999: Sinclair, B., 'More than an act of faith? Evaluating learner autonomy'. In C. Kennedy (ed.) Innovation and Best Practice in British ELT. London: Longman (in association with the British Council).

Smith 2000: Smith, R. C., "Starting With Ourselves: Teacher-Learner Autonomy in Language Learning" in Sinclair, B., McGrath, I. and Lamb, T. ed., Learner Autonomy, Teacher Autonomy: Future Directions, pp. 89-99. Longman, London.

Snow 2001: Snow, M. A., "Content-Based and Immersion Models for Second and Foreign Language Learning" in Celce-Murcia M. (ed.), Teaching English as a Second or Foreign Language, pp. 303-315. Heinle \& Heinle, USA.

Wallace 1998: Wallace, M., Action Research for Language Teachers. Cambridge: Cambridge University Press.

Waters 1988: Waters, A., Teacher training course design: a case study. ELT Journal, Vol. 42/1: 14-20. Oxford: Oxford University Press. 
Wenden/Rubin 1987: Wenden, A. and Rubin, J., Learner strategies in language learning. Prentice Hall International.

Westwood/Arnold 2004: Westwood P. and Arnold, W., "Meeting individual needs with young learners" ELT Journal, Vol. 58/4: 375-378. Oxford: Oxford University Press.

Westwood 2002: Westwood, P. S., Are we making teaching too difficult? A critical look at 'differentiation' in the classroom. Hong Kong Special Education Forum 5/1: 13-29. Hong Kong.

Woodward 1991: Woodward, T., Models and Metaphors in Language Teacher Training: Loop input and other strategies. Cambridge University Press.

Wright 1987: Wright, T., Roles of teachers and learners. Oxford: OUP.

\section{УЧЕСТАЛОСТ И УПОТРЕБА СТРАТЕГИЈА УЧЕЊА СТРАНОГ ЈЕЗИКА: КОМПАРАТИВНА СТУДИЈА}

$$
\text { Резиме }
$$

Циљ овог рада је да објасни учесталост и употребу стратегија за учење страног језика (СУСЈ) као једног од веома важних предуслова за успешно учење на универзитетском нивоу које појединац може имати. И ефикасност и квалитет наставе енглеског језика предствљају важне чиниоце квалитета учења на универзитетском ниову. Штавише, компетнције студената зависе од квалитета и постигнућа која се стичу током педагошких задатака на енглеском језику, како у области језика тако и што се тиче читања литературе на енглеском језику за посебне сврхе. Читање литературе на страном језику допринеће ефективном одношењу према будућим професионалним задацима студената. Главни циљ овог истраживања је да се утврди учесталост употребе стратегија за учење енглеског као страног језика на Педагошком факултету у Јагодини и Филолошко-уметничком факултету у Крагујевцу. Фокус овог истраживања је да се упореде две групе студената што се тиче употребе СУСЈ и да се објасне разлике које се могу појавити. Потенцијал резултата овог истраживања налази се у претпоставци да подучавање стратегијама за учење страног језика на универзитетском нивоу може да има за циљ да помогне студентима да користе енглески језик на ефективнији начин како би унапредили своје будуће професије.

Кључне речи: стратегије за учење језика, ИСЗСЈ (инвентар стратегија за учење страних језика), енглески језик, студенти на универзитетском нивоу

Ивана Ћирковић-Миладиновић

Маријана Д. Матић 